ば，所期の目的は详せられよう。な掞，この方式の難 点が信号の選択回路にあることから，分析管のイオン コレクターを 2 個にして，回路中でイオン流の選択を しないで斉む方式によつて任意のイオン流の強度の比 を直読する装置を考案し，目下試作研究中である。
本研究の具施にあたり，研究班長の份々木明二教授 より絶えず御激污を賜つたことを深く感謝致します。

文献

1） H. Ezoe：J.S.R.I. (欧文科研報仵) , 47, 65(1953)

\title{
タングステン線条の炭化処理に関する研究（第1 報）
}

\author{
早川晃雄炈, 中川㴟三蚛冰
}

(昭和 32 年 8 月 10 日受理)

\section{1. 緒言}

感度およびパターン係数の安定度を保つために，周 知のように分析用質量分析計では電子放射用タングス テン線条の処理をおこなう。タングステン線条の仕事 函数は表面状態によつてかなり釦敏に変動し，これと 接触する気体の種類によつても異なるから，フィラメ ントから放射された電子のイオン化室内における空間 的分布 (位置と密度) の微小変動が起り, 感度および パターン係数の安定度を損うと考えられている(1),2)。 さらに電子放射用タングステン線条は高温であり，タ ングステンは非常に触媒作用が強いから，フィラメン 卜表面では酸化, 還元, 分解等の化学反応か相当活潑 に起り,フィラメントの温度が部分的に変動したり反 応生成物が一部イオン化室へ拡散したりして感度やパ ターン係数が変動することも無視できない。フィラメ ントを処理しないと放射電子のエネルギー巾が大きい との意見には筆者は賛成できない。そうだとしたら仕 事函数の比較的小さい酸化物院極を使用するか，適当 な方法で電子のエネルギー币をしぼれば，フィラメン 卜に起因する感度およびパターン係数の安定度の問題 は解決されるはずである。

試料ガスを導入した場合に，仕事函数の変動を極力 防ぐとともに化学反応を抑制するために，通常タング ステン線条をたとえばブテンのような不飽和荻化水素 で処理して，タングステン表面上に安定な炭化物の層 を形成させる炭化処理が行われる1),3),4)。しかしこれ らの文献を見ても, 炭化物の棈造と処理条件との関 係，感度およびパターン係数の安定度と荻化層の構造 との関係，処理用炭化水素の選択等についてはあまり

* 大阪府立大学教養部化学教穿（堺㲿百舌鳥東之盯）

**大阪府立大学工学部応用化学教室（同上）
明りようでない。しかも気体との接触による仕軎函数 の変動や化学反忘は試料気体の種類によつて異なり, 炭化物も水分や酸素等とは当然活潑に反応すると考え られるから，厅能処理法などはあるわけがない。とか く一子相伝的な秘伝の発生するゆえんであろう。

本研究は炭化処理の条件と炭化層の構造との関連を 明かにする目的から，犋量分析計のイオン源とは多少 異つた条件の下に行つたものである。何分研究が開始 されてから日も浅いらえに計画も不充分であるから， 预櫵垁験的な結果で系統性が牦いが一応の結果を御報 貨して御教示を仰ぐ次第である。

\section{2. 実 験 装 置}

装買の配蔡を第 1 図に略示した。 $\mathrm{V}$ は反応管， $\mathrm{G}_{1}$ は電離真空計， $\mathrm{G}_{2}$ は回転 McLeod 点空計，Lは孔 径約 $2 \times 10^{-2} \mathrm{~mm}$ のガラス製オリフィス型ガスリー ク， $\mathrm{R}_{1}$ は体積約 1 リットルの 2-ブテン (Philips, research grade) のガス溜, $\mathrm{R}_{2}$ は $n$-ブタン(Philips, research grade) のガス留（体積約 1 リットル), $\mathrm{B}_{1}$ および $\mathrm{B}_{2}$ はそれぞれ体樻約 3 リットルの膨脤用バル ブ， $\mathrm{M}$ は水銀国力計， $\mathrm{T}_{1}$ および $\mathrm{T}_{2}$ はトラップで 液体案素を用いて冷却する。排気には 3 段ヒックマン

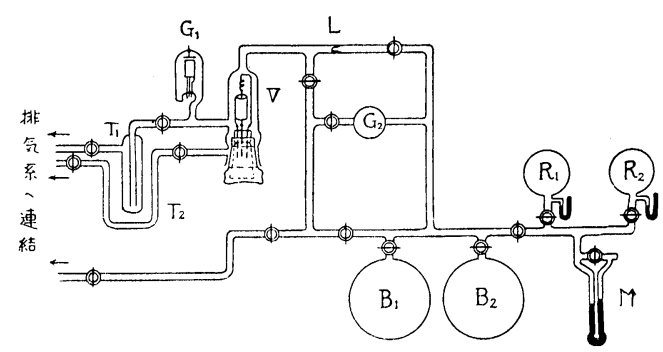

第 1 図装蛘略図 


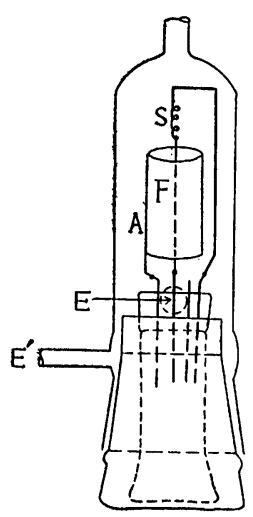

第 2 図 反応管

型油拡散ポンプおよび $50 l / \mathrm{min}$ の油回転ポンプを使 用しだ。

反応管（第 1 図，V）の紐部を第 2 図に示した。F は佀径 $0.3 \mathrm{~mm}$; 長さ $35 \mathrm{~mm}$ のタングステン線条(単 線), Aは内径約 $18 \mathrm{~mm}$, 辰さ $25 \mathrm{~mm}$ のモリブデン 誃问简状陵極，Sはフィラメントに浱力をかけるため

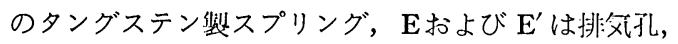

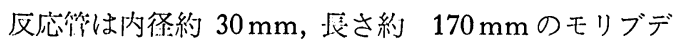
ンガラス留で下部はスリ合せになつている。

\section{3. 実 験 条 件}

装罱备部（第 1 図の $\mathrm{R}_{1}$ および $\mathrm{R}_{2}$ を除いて）を充 分に排訤した後，タングステン線条のフラッシュを行 い，さらに第 1 翌に示した条件でフィラメントの前処

符 1 表 フィラメントの前処理条件

\begin{tabular}{|c|c|c|c|c|}
\hline 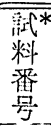 & 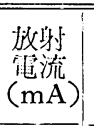 & 加警電流 (A) & 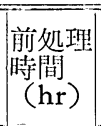 & $\begin{array}{l}\text { 反応管の具宽 } \\
\text { 度 }\left(\mathrm{mmHg}^{* *}\right)\end{array}$ \\
\hline 1 & 5 & $7.6 \rightarrow 6.9$ & 8 & $7 \times 10^{-6}$ \\
\hline 2 & 8 & $8.1 \rightarrow 7.2$ & 6 & $5 \times 10^{-6}$ \\
\hline 3 & 10 & $9.1 \rightarrow 7.5$ & 5 & $6 \times 10^{-6}$ \\
\hline 4 & 10 & $9.0 \rightarrow 7.4$ & 5 & $6 \times 10^{-6}$ \\
\hline 5 & 5 & $7.6 \rightarrow 6.8$ & 8 & $6 \times 10^{-6}$ \\
\hline 6 & 8 & $8.0 \rightarrow 7.2$ & 6 & $6 \times 10^{-6}$ \\
\hline 7 & 5 & $7.7 \rightarrow 6.8$ & 8 & $5 \times 10^{-6}$ \\
\hline 8 & 8 & $8.1 \rightarrow 71$ & 6 & $6 \times 10^{-6}$ \\
\hline 9 & 10 & $9.1 \rightarrow 7.5$ & 5 & $5 \times 10^{-6}$ \\
\hline
\end{tabular}

* 整理番号であつて，実験の順原を示すものではな w。

**符 1 図に示した位㯰の電滩五空計で测定した偵。
第 2裴フィラメントの岸化処理条件:

\begin{tabular}{|c|c|c|c|c|c|}
\hline & $\begin{array}{l}\text { 成射 } \\
\text { 䨪流 } \\
(\mathrm{mA})\end{array}$ & 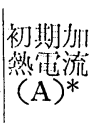 & $\underset{\substack{\text { ガス } \\
\text { 光** } \\
(\mathrm{mmHg})}}{ }$ & $\begin{array}{l}\text { 処玨 } \\
\text { 待間 } \\
(\mathrm{hr})\end{array}$ & 処理 ガ ス \\
\hline & 5 & 7.3 & $2.5 \times 10^{-4}$ & 7 & 2-ブテン \\
\hline & 8 & 7.7 & $2.1 \times 10^{-3}$ & 7 & 2-ブテン \\
\hline & 10 & 8.4 & $1.3 \times 10^{-3}$ & 7 & 2-ブテン \\
\hline & 10 & 7.9 & $5 \times 10^{-4}$ & 7 & 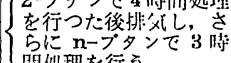 \\
\hline & 5 & 7.2 & $2 \times 10^{-4}$ & 7 & 同上行 \\
\hline & 0 & 7.5 & $7 \times 10^{-4}$ & 7 & 2-ブテン \\
\hline
\end{tabular}

理を行つた。第 1 表にあげた試料のうち $7 ， 8 ， 9$ の各

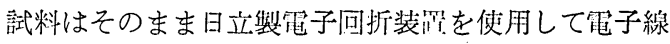
回折像を摄り単結昆化の程度を検查した。また陚料番 号 1〜6については第 2 表に示した条件のもとに炭化 処理を行い，排気後さらに 1 時間然成 (aging)を行つ た後電子線回折像を捛影した。

\section{4. 実験結果および考察}

\section{$4 \cdot 1$ フィラメントの前処理の結果}

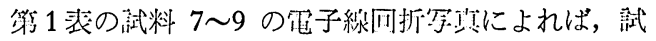
料 7 (政射電流 $5 \mathrm{~mA}$, 加然電流 $6.8 \mathrm{~A}, 8$ 時問処理)

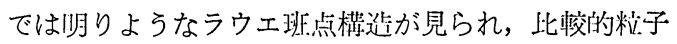
の大きなタングステンの単結蜀化が起つたと考えられ る。これに対して靯料 9 (放射龟流 $10 \mathrm{~mA}$, 加㠇電流 $7.5 \mathrm{~A}, 5$ 洔間処理）の回折像は環状配位で, 結暃の粒 子が細く分散している事を示している。垔料 8 (班射 電流 $8 \mathrm{~mA}$, 加愁電流 7.1 $\mathrm{A}, 6$ 時間処理）の電子綵 回折像は倵料 9 に類似している。

\section{$4 \cdot 2$ フィラメントの炭化処理の結果}

第 2 表にあげた諸試料のうち，陚料 5 および 6 は電 子線回折像の报影に失敗したので除外し，1 4 の試 料についてフィラメントの加槊電流（一定の放射電流 を得るに必要な）の変化抢よび電子線回折像の解析結 果を検钶する。

炭化処理によるフィラメントの加整電流の変化を第

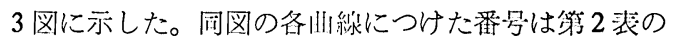
各征料番号にそれぞれ対応している。実験回数が少な く测定方法にも不傎な点があるので，断定的なことは 諭じられないが，第 3 図および第 2 淁から考えるとこ の実験条件では次の傾问があるように思われる。

*一定王の処理ガスを反応管に流し，放射電流を所定 の佔に調整した時の加䓡電流。

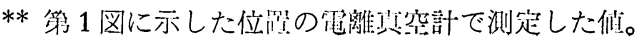




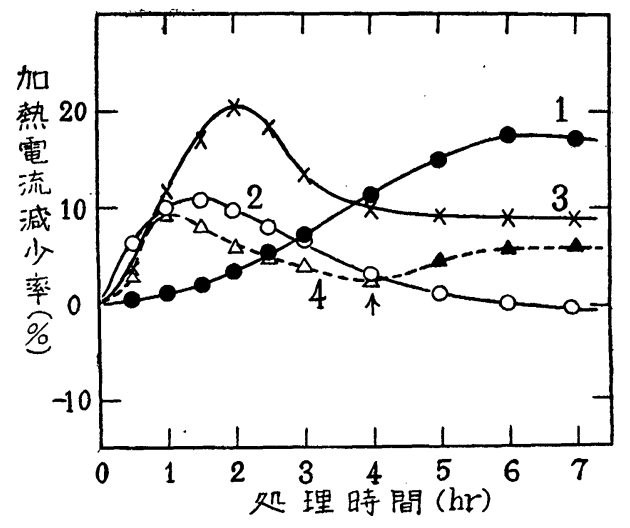

第 3 図 加熱電流の変化

（1）放射電流（従つて加熱電流）および炭化処理 気体（2-ブテン）の圧力がともに比較的小の場合に は, 加熱電流は処理時間の増大につれて単調に減少し ほぼ飽和値に達する（第3 図曲線 1 )。

（2）放射電流（従つて加熱電流）が比較的大の場 合には，2-ブテンで炭化処理を行つたものについて に, 炭化処理気体の圧力には無関係に, 加熱電流の減 少率は約 2 時間で最大值に達し, 処理時間がさらに增 すと加熱電流の減少率はがえつて減少し, 比較的速か に平衡值に達する場合と初期における加熱電流の值ま で实つてくる場合とがある（第 3 図曲線 2,3，および 4 の个印まで)。

（3）放射電流（従つて加熱電流）が比較的大の場 合に, 一定時間 2-ブテンで炭化処理を行い加熱電流 の減少率が最大值を経てかえつて減少した状態下で, 排気後さらにほぼ同圧の $n$-ブタンで引続き炭化処理 を行えば加熱電流はふたたび減少し約 2〜3 時間でほ ぼ飽和値に達する（第 3 回曲線 4 の $\uparrow$ 印より右の部 分)。

第 2 図の反応管で测定している各放射電流が飽和電 流であるか否かについては検討が不充分であり，また タングステン線条の温度を直接測定していないから， 第 3 図に示された加熱電流の変化が直ちにタングステ ン表面の仕事函数の変化に対応するものと断定するこ とは危険かも知れない。しかし上記の各実験ではフィ ラメントの加熱回路の電圧はそれぞれ一定であるか ら，加熱電流の変化は一定の放射電流を得るに必要な フィラメントの温度の変化を示すものであり, フィラ メント表面の仕事函数の変化を間接に示しているもの と解してもよい様に思われる。

筹者の研究室で日立 RMC 型イオン源》についてフ ィラメント（直径 $0.1 \mathrm{~mm}$, スパラル）を 2-ブテ
ン，2-ブテン $\rightarrow n$-ブタンで炭化処理を行つた場合， および日立 RMU-5 型と同一のブロック型イオン源 についてフィラメント（值径 $0.2 \mathrm{~mm}$, 単線）を 2-ブ

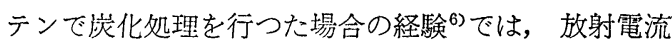
および炭化処理ガス圧は共に本実験に比して小である が，加熱電流と処理時間との関係はいずれも第 3 図の 曲線 1 と類似の傾向にある。

第 2 表（および第 3 図）の条件で 7 時間炭化処理を 行つた後さらに真空中で 1 時間加熱熟成を行つた各試 料について，それぞれ電子線回折像を撮り解析を行つ た結果はかなり複雑である。銀を標準に選んで銀の回 折環半径と面間隔とからカメラ定数を求め, この值を 用いて試料 2 の回折像の解析を行つた結果を第 3 表に 示した。

第 3 表 試料 2 の回折像解析結果*

\begin{tabular}{c|c}
\hline $\begin{array}{c}\text { 回 析 環半径 } \\
r(\mathrm{~mm})\end{array}$ & 面 $\begin{array}{c}\text { 間 } \\
d(\AA)\end{array}$ \\
\hline 7.68 & $\begin{array}{c}\text { 隔 } \\
(\AA)\end{array}$ \\
8.63 & 2.40 \\
10.64 & 2.14 \\
14.31 & $1.73_{5}$ \\
15.13 & $1.29_{0}$ \\
& $1.22_{0}$ \\
\hline
\end{tabular}

第 4 表 試料 2 と $\beta-W_{2} C$ との比較

\begin{tabular}{ccc|c|c}
\hline \multicolumn{3}{c|}{$\beta-W_{2} C$ (hexagonal) } & 試料 2 の面間隔, \\
$d$ (実測值, $\mathrm{A}$ )
\end{tabular}

第 3 表に得られた試料 2 の面間隔は $W\left(a_{0}=3.147\right.$

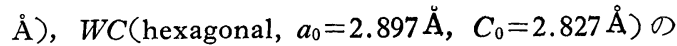
いずれの面間隔の計算值とも明らかに異なる。しかし 第 4 表に示したように $\beta-W_{2} C$ (hexagonal, $a_{0}=2$. $99 \AA, C_{0}=4.72 \AA$ ）の面間隔の計算値と比較的良く一 致している。

試料 3 の回析像について同様に（金を標準としてカ メラ定数を測定して）面間隔を求めた結果は； $W$,

*比較的明りような回析環だけを選択した。 
$W C$ (hexagonal), $\beta-W_{2} C$ (hexagonal)のいずれの面 間隔（計算值）とも一致しない。しかし工業的に製造 された WC 粉末の電子線回折像を撮り, 阔者（同一 条件）の回折環半径を比較すると第 5 装となる。

第 5 表 焉料 3 と $W C$ 粉末との比較

\begin{tabular}{|c|c|}
\hline $\begin{array}{c}\overline{W C} \text { 粉末の回折環半径 } \\
r(\mathrm{~mm})\end{array}$ & $\begin{array}{c}\text { 試料 } 3 \text { の回折環半径 } \\
r(\mathrm{~mm})\end{array}$ \\
\hline 4.48 & - \\
\hline 6.70 & 6.03 \\
\hline 8.03 & - \\
\hline 9.06 & 8.89 \\
\hline 11.20 & 10.94 \\
\hline 14.32 & 14.86 \\
\hline 16.27 & - \\
\hline
\end{tabular}

試料 1 の回折像の解析結果はやや試料 3 の結果に類 似しているが，试料 4 の解析結果は上記のいずれとも 一致しない。以上の結果から考えると, 炭化処理の条 件と生成した炭化層の構造との関連はかなり複雑であ り, 今後さらに数多くの実験を行わぬ限りはつきりし た或は論じられない。しかし上記の結果からわかるよ うに，2-ブテンによる炭化処理（7時間の）によつて 加慜電流（従つてフィラメント表面の仕事函数）がほ とんど最初の值にもどつたような状態の場合には $\beta$ $W_{2} C$ の構造を有し, 炭化処理（2-ブテンによる7時 間の) の結果フィラメント表面の仕事函数が最初の夕 ングンテン表面の値よりかなり減少している場合には
炭化層は $W C$ 粉末に近い構造を有するものと思われ る。しかし第 3 図に示した加熱電流の変化の各点につ いて炭化層がどのような構造を有するかについてはさ らに今後研究を続行しないとわからない。

な打本研究を行うに際して, 炭化用試料ガス（2-ブ テン, $n$-ブタン) を頂いた丸善石油株式会社中央研究 所の上妻常英課長および大島晶三氏に感謝するととも に, 各試料の電子線回折像を摄影して顶き解析につい ても御教示を顶いた大阪府立大学工学部金候学教空目 良氏に感謝する。

文献

1) G.P. Barnard, Modern Mass Spectrometry, Inst. Physics (London), p. 206 (1953).

2) A.J.B. Robertson, Mass Spectrometry, Methuen (London), p. 88 (1954).

3) M.R. Andrews and S. Dushman, J. Franklin Inst., 192, 545 (1922).

4) M.R. Andrews and S. Dushman, J. Phys. Chem., 27, 270 (1923).

5）早川晃雄・杉浦俊男, 質是分析，5，35（1955） 参照。

6) 結果の一部 (RMC 型イオン源) は昭和 30 年 9 月の睤量分析研究会委員会 (真京, 学術会議) お よび昭和 30 年 10 月名古屋大学工学部における 昭和 30 年度斦量分析秋期等演会に打いて発表。

\title{
質量分析計による炭化水素分析の精度と確度
}

\author{
㮛田勉”
}

(昭和 32 年 8 月 17 日受理)

\section{序言}

よく知られているように，質量分析計により分析し たとき，オシログラムまたはペン記録となつたその試 料のマススペクトラムしか提供されなければ, 試料の 成分を identify することはできないし，また各成分 の量を決定することもできない。一般に化学分析に物 理的方法が適用されたときには，いわゆる calibrat-

* 京都大学理学部化学教室 (京都市左京区吉田) ion が不可欠であるが，啠量分析計においてもこれは 省略することのできないことであつて，上に述べた試 料のマススペクトラムに加えて, 存在を予想される成 分のパタン係数と感度とがあたえられないかぎり、、 ススペクトラムの解析は不可能である。

このような事情が必ずしも一般に一一なかんずく啠 量分析を依頼する方方に一一認識されていないように 思われる。したがつて試料瓶 1 個を持参すればすぐに でも分析值が得られるという期待をもつて, 娦量分析 について照会を受けることがよくある。都合の悪いこ 